\title{
The Renvoi in Private International Law
}

\author{
Berlingher Remus Daniel
}

\begin{abstract}
In the present paper I have analyzed the institution of renvoi, institution specific to the international private law, because it indicates importance from theoretical point of view and practical point of view, too. Thereby, the renvoi interferes in case of a negative conflict of laws which take place related to a juridical report with a foreign element. In this case the question arises whether the report will be settled by the law, because both the conflict norm of the approached court of law and the foreign conflict norm are declaring themselves unqualified in solving the refered to report. Thus, renvoi reperesents the juridical situation emerged when the conflict norm of the approached court of law refers to a foreign law system, and this, by its own conflict norm, doesn't get the competence which is adjudged to it and it sends back to the forum law, or sends farther to a law of a third party state.

In the present paper $I$ have in mind to answer to this question, analysing this institution specific to the international private law.
\end{abstract}

Index Terms - Competent law, conflict of law, foreign element, negative conflict, renvoi.

\section{Preliminary Considerations Concerning the}

JURIDICAL REPORT WITH AN ELEMENT OF EXTRANEITY, REGARDING THE CONFLICT OF LAW AND CONFLICT NORMS

The foreign element (of extraneity) establishes the main element through which the juridical reports of international private law differ from the juridical reports of internal law.

In the absence of a legal definition, the element of extraneity has received doctrine definitions quite similar. Thus, for example, "the element of extraneity represents a circumstance de facto due to which a juridical report is related with two or more law systems"[1]-[2] or "the element of extraneity represents a circumstance de facto which is related to one or more elements of structure of the juridical report and which has the ability to bring into discussion the possibility of applying the foreign law"[3]-[4] or "the element of extraneity represents a circumstance de facto of diverse nature, which is related to a juridical report of private law, circumstance which gives the respectively juridical report an international aspect."[5]

The stated definitions in the speciality literature converge towards the idea that the element of extraneity represents a de facto circumstance which interconnects the juridical report with one or more law systems, susceptible of enforcement.

As far as I am concerned, I consider that the element of extraneity represents a de facto circumstance related to the elements of the juridical report, due to which to that particular juridical report can be enforced one or more law systems.

Manuscript received September 26, 2012; revised November 30, 2012.

Berlingher Remus Daniel is with the "Vasile Goldis" Western University Arad, România (e-mail: berlingherdaniel@yahoo.com).
The conflict of laws emerges when to a juridical report with an element of extraneity, are susceptible to be enforced two or more laws belonging to different law systems, systems to which the juridical report has a connection through the element of extraneity [6]. For example, in case of closure a deed of conveyance of an article situated abroad, if the parties have different nationalities, the juridical report has several elements of extraneity and there are more laws called to settle it. Thus, there is the national law of the parties for the capacity of contract, the law of the place of the closure the document for its form, the law of the place of laying the asset for problems which are related to the real status of the asset.

Usually, the conflict of laws appears between the law of the country (jurisdiction) approached in solving the litigation (lex fori) and the foreign law with whom the report is connected through its own foreign element. These laws can be found in conflict, because both are susceptible to be applied to the juridical report with a foreign element, case when the approaches jurisdiction will chose one of the laws in presence, the one it is going to apply.

Regarding the settlement of the juridical report with an element of extraneity, according to the conflict norms method, in each situation in which an authority of jurisdiction is invested with the solving of a litigate with an element of extraneity, to whom are susceptible to be applied two or more foreign law systems, the conflict norm of the forum will be used [7].

The conflict norm represents that juridical norm specific to the international private law, which solves the conflicts of laws, in the sense that, it settles which one of the law systems in cause must be applied regarding the juridical report with an element of extraneity. For that matter, the conflict norm does not settle the juridical report with a foreign element. It only indicates the competent law to settle direct the referred to report. With the help of the conflict not we can choose which one of the internal laws is the law which must be enforced. From the moment when the internal law enforced was settled (competent), the action of the conflict norm stops and the norm of internal law is enforced, law which will rule the juridical report with an element of extraneity.

\section{The Notion OF RENVOI}

The renvoi is an institution of Private International Law that allows the possibility for the foreign law declared as competent by the conflicting norm of the forum court, to decide in turn, to make a renvoi through its own conflicting norms, to another law, either to the approached court's law, or to the law of a different legal system [8]-[10].

The renvoi implies a conflicting between conflicting norms. This conflict can be positive or negative.

We can state the presence of a positive conflict between 
the conflicting norms (between the conflicting norm of the forum court and the foreign conflicting norm declared competent) when both conflicting norms stipulate that their own law is competent to regulate the judicial relation with foreign element. For instance, to regulate the succession of an Italian citizen who owned an immovable property in France, the French conflicting norm declares competent the law of the place where the property is located, in the French law, while the Italian conflicting norm declares competent the Italian national law of the citizen, ie the Italian law. In this case, the positive conflict arises between the French conflicting norm and the Italian conflicting norm.

In the case of the positive conflict, there will be no renvoi because this conflicting will be solved in the sense that the court will take into account its own conflicting norms. If the issue is to be solved by the French court, the French conflicting norm will be applied, and if the issue is raised to the Italian court, the Italian conflicting norm will be applied.

As for the negative conflict, both conflicting norms in presence declare unqualified their own material law to manage the judicial relation with element of extraneity. In this case, the forum law court pronouncing itself as unqualified to manage the judicial relation, assigns this responsibility to another law, meaning it refers to another foreign law. If the latter does not accept the given competence and declares competent another law (that of the Court of the judicial forum or that of a third country) regarding that judicial relation, renvoi to that law. For instance, in terms of capacity, if an English citizen, residing in Romania, according to the Romanian conflicting norm, the national law [11] applies, in the English law, as the issue is about an English citizen, but, according to the English conflicting norm, the law of the residence will be applied, in the Romanian law, as the English citizen resides in Romania.

Concluding we can affirm that the renvoi functions only for a negative conflicting and only if the renvoi is pointed to the entire foreign law system, including its conflicting norms, these norms may accept or not the remission, by declaring themselves unqualified and order a new referral, thus performing the renvoi.

\section{THE FORMS OF RENVOI}

\section{A. There are Two Forms of Renvoi, Namely}

First degree renvoi or single renvoi is that form when the foreign law refers to the forum law, and if the renvoi is accepted, the approached court shall apply its own domestic law. Theoretically, the discussion of renvoi was determined by the Forgo case[12] that consisted of the following elements: a Bavarian illegitimate child, named Forgo, was brought to France from the age of 5 years, and lived most of his life in France, without ever acquiring an official domicile, because he never met the French law conditions. Therefore, according to the French law, he remained a Bavarian citizen legally residing in Bavaria. After his death, multiple important movable properties remained, and his collateral relatives introduced to the French court "a petition of inheritance". According to the French law, the movable succession was under the national law of the deceased (in the Bavarian national law), that stated the inheritance on maternal lineage for the collateral relatives. However, the French courts had established that the Bavarian conflicting norm regarding the movable succession sent back to the French law, because, according to the Bavarian conflicting norm, the movable succession is subject to the law of the deceased's real domicile. Consequently, the Bavarian conflicting norm does not accept the sending, but sends back to the French law system. Accepting the renvoi, the French court applied the French succession lay, according to which maternal side relatives were not allowed to inherit. Thereby, Forgo's succession became vacant and the movable property located on French territory became part of the French State.

Second degree renvoi or complex renvoi [13] is that form in which the foreign law returns to a third state law and not to the law of the judicial forum. For instance, a Danish citizen (whose personal law is the law of the domicile) would reside and die in England and a French court would be informed about a dispute concerning his movable succession; the French law will refer to the national law of the deceased (the Danish law), that, in turn, refers to the domicile law (the English law), which accepts the renvoi. Finally, the English succession judicial system as the law of the deceased domicile will govern his movable succession.

\section{ARguments In Support of THE AdMISSION OF THE RENVOI [14]-[18]}

The following arguments in support of renvoi were brought in states' laws or in jurisprudence:

1) The need of interpreting the foreign law for the purpose of including the conflicting norms too. The remission to foreign law is considered to be a remission to the whole system of law, including to its conflicting norm. First and foremost, this aspect is motivated by the fact that renvoi almost always functions in favor of the law of the judicial forum, and secondly, there is a close connection between the foreign material law and the foreign conflicting norm.

2) The foreign law has to be applied when it self-declares competent. Renvoi demands to be admitted; otherwise, it will mean that the foreign law will be applied to an area where it declares itself unqualified.

3) The renvoi ensures the enforcement of judgments. The judgment will be efficient only as an effect of admitting the renvoi, because, from all the states where it is possible to invoke its effects, most likely is the state whose law is connected with the legal relationship, through its foreign element.

4) Second degree renvoi can be a means of coordination of law system in the presence, if one of those law systems does not accept the renvoi. The impossibility to determine the competent law in case of second degree renvoi can be avoided by applying the material law indicated by the conflicting norm of the judicial forum, or by the material law of the judicial forum; considering that the second degree renvoi can provide the synchronization of the solutions provided by the laws in 
presence.

\section{Arguments Against the Admission of the RENVOI[19]-[21]}

1) The appropriate conflicting norm is that of the judicial forum. In private international law there is a principle according to which the conflicting norm of the judicial forum is applied and not the one of the foreign law system, and if the renvoi is accepted, it would mean that this principle is no longer endorsed, as the competent court for solving the case would guide itself by the foreign conflicting norm to determine the appropriate law.

2) The renvoi may lead to a continuously loop of new cases of renvoi (an inextricable circle). If the first remission imposed by the conflicting norm of the judicial forum is considered as referring to the whole foreign law system, then the renvoi must also be referred to the whole law system of the judicial forum, including its conflicting norms. In this case, the declared unqualified conflicting norm disposes a new renvoi to the foreign law which in turn returns again to the law of the judicial forum and so on. If the renvoi is acknowledged it means an arbitrarily exit of this inextricable circle.

3) The admission of the renvoi generates uncertainty regarding the legal solution. The renvoi can not be accepted because it increases the uncertainty in private international law and constitutes an exception to the normal cases of application of the foreign law. For these mentioned reasons several treaties and international conventions no longer allow the renvoi [22].

\section{CASES FOR NON-APPLYING RENVOI}

The renvoi does not apply in the following cases:

1) In case of the autonomy of will, when the parts have chosen the law applicable to their contract. In the absence of willpower manifestations, it is assumed that they agreed to choose the existing arrangement for that contract in that specific system of law [23].

From the principle of the will autonomy results the fact that, in the matter of the contract reports, if the suited law was chosen, it is off cast the renvoi when an act of will of the parties is missing in this case. Although there might happen the fact that the conflict norms of a country to whom the suited law belongs would not admit the competence for this law, it must do a remit, it won't be taken into consideration the stipulation of this conflict norm, because we can assume the fact that the parties have figured out to choose the existent regulation for that contract in that particular law system, with the exclusion of its conflict norms.

2) When applying the "locus regit actum". In this case, the remission made by the conflicting norm regards the law stipulations of the place where the act was completed regarding its outward form, without taking into account the conflicting norms of the legal system in question.

3) When the second degree renvoi does not allow the determination of the applicable law.

\section{THE RENVOI IN THE ROMANIAN LAw[24]}

As a general rule, the Romanian law allows only first degree renvoi. This rule is established by art. 2559 paragraph 2 of the Romanian Civil Code that states "if the foreign law appointed according to the Romanian conflicting norm remits to the Romanian law, the Romanian law applies, unless expressly provided otherwise".

Regarding the second degree renvoi, this is not allowed. The renvoi made by the foreign law, to another state law, has no effect, by applying the Romanian law, unless expressly provided otherwise.

The implementation of the material Romanian law, in this case isn't done on the strength of the will of the foreign conflict norm, but as a result of the recognizance of the renvoi [25].

When the renvoi is accepted, under the conditions appointed by the art. 2559 Romanian Civil Code, the rule of international foreign private law is taken into consideration in the existent form and content at the moment of the identification of the suited foreign law [26].

Although the dispositions of the art. 2559 Romanian Civil Code consecrate the rule of the receiving of the renvoi of first degree in the Romanian law system, there are exceptions from this rule.

Thus, for example according to the international regulations [27], in case of the uncontractual statements, the renvoi is not possible, because it is not foreseen by the material foreign law, but by the conflict foreign norm (which is excluded from enforcement).

The explanation given for this exception has a different content dependent on the interested parties' attitude. Thus, if the interested parties have chosen the foreign law, there is the relative presumption that they only related to the material norms [28].

In the absence of a law applicable to the contract, the law of the form of the juridical document is determined through the objective localization according to the art. 2638 par. 1 Romanian Civil Code which stipulates that "when the choose is missing, the law of the state with whom the juridical document has a close connection is enforced, and if this law can not be identified, the law of the closure of the juridical document will be enforced." This principle is incompatible with the institution of renvoi [29].

To the above - mentioned exception we cad add all the other situations settled by the Romanian Civil Code, when there is applied the rule locus regit actum [30].

As a result, if the Romanian conflict norm refers to a foreign law system, and the late one, by its own conflict norm refers farther to the law of a third party state, as a rule the Romanian law will be enforced, the renvoi made by the third party state will remain without effect.

\section{CONCLUSION}

In the present paper I have tried to analyse the institution of renvoi, institution specific to the international private law.

From the actions mentioned above, it can be concluded the fact that the institution of renvoi has an importance both from theoretic point of view, and from practical point of view. 
It is important for us to know this institution, because when a juridical report with a foreign element generates a litigation, hoe will be solved that litigation if the conflict norms with whom the report has a connection, declares itself incompetent in solving the mentioned litigation.

Thus, the renvoi intervenes when the conflict norm of the approached court of law sends to a foreign law system, and this, by its own conflict norm, does not receive the competence which is attributed to it and it either sends back to the law forum, or sends farther to the law of a third party state.

We can state that if the renvoi would not be admitted, it means that the foreign law will be enforced in an area where it declares itself incompentent.

Furthermore, there are cases when the renvoi can not function, when the court of law does not refer to the entire law system but only to some accurate material regulations. At the same time, the renvoi is not accepted in all law systems and when it is accepted there are cases when it can not function: in the case of the will autonomy of the parties it is assumed that they refered to a certain law system with the exclusion of the possibility of renvoi, the citizenship - the determination of the citizenship excludes the possibility of the renvoi, the rule locus regit actum excludes the possibility of the renvoi, too because it is taken into consideration only the material disposals of the law of the place and not of the entire law system.

\section{REFERENCES}

[1] A. Fuerea, Private international law, $2^{\text {nd }}$ revised and enlarged edition, Universul Juridic Publishing House, Bucharest, 2005, pp. 19.

[2] I. Macovei, Private international law, $2^{\text {nd }}$ edition, Publishing company Ars Longa, Iasi, 2001, pp. 25.

[3] O. Ungureanu, C. Jugastru, and A. Circă, Companion of international private law, Publishing company Hamangiu, Bucharest, 2008, pp. 7.

[4] D. Lupaşcu and D. Ungureanu, Private international law, Universul Juridic Publishing House, Bucharest, 2012, pp. 12-13

[5] T. Prescure and C.N. Savu, Private international law, Lumina Lex, Bucharest, 2005, pp. 24.

[6] I. P. Filipescu and A. I. Filipescu, Private International Law Treaty, Universul Juridic Publishing House, Bucharest, 2005, pp. 33.

[7] Romanian explanatory dictionary. [Online]. Available: http://www.dexonline.ro/definition/

[8] D. Lupascu and D. Ungureanu, op. cit., pp. 78.

[9] T. R. Popescu, Private international law, Romfel Publishing House, Bucharest, 1995, pp. 71.

[10] I. P. Filipescu, Private international law, vol. I, Actami Publishing House, Bucharest, 1995, pp. 114.

[11] The Romanian Civil Code. [Online]. Available: http://www. cdep.ro/pls/legis/legis_pck. frame
[12] B. Ancel and Y. Lequette, Grands arrêts de la jurisprudence francais de droit privé, $2^{\text {nd }}$ ed., Paris, Sirey, 1992, pp. 53-60, 1878.

[13] D. Lupascu and D. Ungureanu, op. cit., see reference, no. 2, pp. 79.

[14] H. Batiffol and P. Lagarde, Droit international prive, $7^{\text {th }}$ ed., Paris, Librairie générale de droit et de jurisprudence, 1983, pp. 365-366.

[15] P. Mayer and V. Heuzé, Droit international privé, 10 edition, Éditions Montchrestien, Lextenso editions, 2010, pp. 164.

[16] S. Clavel, Droit international privé, 3 edition, Dalloz, 2012, pp. 46-47.

[17] I. P. Filipescu and A. I. Filipescu, op. cit., pp. 102-107.

[18] A. Fuerea, op. cit., pp. 54.

[19] H. Batiffol and P. Lagarde, op. cit., pp. 362.

[20] I. P. Filipescu and A. I. Filipescu, op. cit., pp. 101-102.

[21] A. Fuerea, op. cit., pp. 55.

[22] D. Lupascu and D. Ungureanu, op. cit., see reference no. 5, pp. 79.

[23] Excluding the possibility of renvoi. [Online]. Available: http://www. hcch.net/index_en.php?act $=$ conventions.text\&cid=31.

[24] Related legislation. [Online]. Available: http://eur-lex.europa.eu/LexUriServ/LexUriServ.do?uri=OJ:L:2007:1 99:0040:0049: ES: PDF.

[25] O. Ungureanu, C. Jugastru and A. Circa, op. cit., pp. 96

[26] Art. 208 paragraphs 3 from Law no. 71/2011 for the implementation of Law no. 287/2009, published in Romania's Official Gazette, Part I, no. 255 of 17 April 2012. [Online]. Available: http://www. cdep.ro/pls/legis/legis_pck. frame.

[27] Art. 24 from The Statute (CE) nr. 864/2007 (ROME II). concerning the law enforced to the uncontractual obligations. foresees that the enforcement of the law of any of the countries mentioned in the present Statute means the enforcement of the norms of law in force in that particular country. excepting its own norms of international private law. [Online]. Available: http://eur-lex.europa.eu/LexUriServ/LexUriServ.do?uri=OJ:L:2007:1 99:0040:0049:ES:PDF.

[28] D. Lupaşcu and D. Ungureanu, op. cit., pp. 82-83.

[29] D. A. Sitaru, op. cit., pp. 89.

[30] For example. art. 2626 paragraph 1 Romanian Civil Code. stipulates the forms of publicity achieved in any way, concerning the goods are committed to the law enforced at the place and time where they can be fulfilled. only if through special measures it is settled something else. [Online]. Available: http://www. cdep.ro/pls/legis/legis_pck.frame.

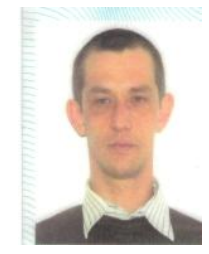

Berlingher Remus Daniel was born in Baia Mare, Romania. His he educational background as follow: Doctor in law, Faculty of Law, "Lucian Blaga" University, Sibiu, Romania, 2010; Master, Communitary Law and Communitary Institutions, Faculty of Law, "Vasile Goldis" Western University, Arad, Romania, 2002; Bachelor in Law, Faculty of Law, 1999 "Vasile Goldis" Western University, Arad, Romania,

He works at the Faculty of Law, "Vasile Goldis" Western University, Arad, as Ph. D. Lecturer. Published books: Berlingher Daniel, Private international Law, Cordial Lex Publishing House, Cluj Napoca, Romania, 2012; Berlingher Daniel, Sida Andrei, The General Theory of Law, Cordial Lex Publishing House, Cluj Napoca, Romania, 2012.

Dr. Daniel is a member of Scientific Committees of $1^{\text {s }}$ Advanced Research in Scientific Areas. 